\title{
PREVALENCE OF FACTORS ASSOCIATED WITH CIGARETTE SMOKING AMONG SPORT FACULTY STUDENTS: A STUDY FROM TURKEY ${ }^{1}$
}

\section{SPOR FAKÜLTESİ ÖĞRENCILERININ SIGARA İÇMESI İLE İLIŞKİLI PREVALANSI: TÜRKIYYE'DEN BIIR ÇALIŞMA}

\author{
Eray YURTSEVEN', Selçuk Bora CAVUSOGLU², Feray KÜÇÜKBAŞ DUMAN", \\ Suzan DAL ${ }^{4}$, Cemile Nihal YURTSEVEN ${ }^{5}$ \\ ${ }^{1}$ Istanbul University-Cerrahpasa, Cerrahpasa Medical Faculty, Department of Public Health, \\ Istanbul / Turkey \\ 2-3-4-5 Istanbul University-Cerrahpasa, Faculty of Sport Sciences, Department of Sports Management, \\ Istanbul / Turkey
}

ORCID ID: 0000-0003-0565-6407', 0000-0003-4163-965², 0000-0002-8265-4037³, 0000-0002-7732-9846 ${ }^{4}, 0000-0001-8201-0752^{5}$

Amaç: Tütün kullanımı iskemik kalp hastalı̆ı̆ı, kanser, inme ve solunum yolu hastalıkları gibi birçok hastalıktan ölüm riskini artırmaktadır. Sadece 2016'da tütün kullanımı dünya çapında 7,1 milyondan fazla ölüme neden olmuștur. Bu ölümlerin çoğun (6,3 milyon) sigara içilmesine, ardından da pasif içiciliğe atfedilebilir. Yöntem: Bu çalışmanın amacı, İstanbul Üniversitesi Spor Bilimleri Fakültesi’nde sigara içme prevalansını ve sigara içme ile ilişkili faktörleri değerlendirmektir. Fakültede eğitim alan 360 öğrenci bulunmakta olup, bir örneklem seçimi yapmadan tüm öğrencilere ulaşılması amaçlanmıştır. Bulgular: Araştırmaya katılmayı kabul eden öğrenci sayısı 294 (\% 81,94) 'dür. Neredeyse $\% 8^{\prime} \mathrm{i}(\mathrm{n}=24)$ günde $10^{\prime}$ dan fazla sigara içtiği belirlenmiştir. Sigara içme prevalansı yaş, oturma yeri, annenin eğitimi, babanın eğitim düzeyi, sigara içilmesi, tütün kullanımı gibi faktörlerle, öğretmenlerin sigara alıșkanlığı ve alkol tüketimi ile ilgili bilgi durumları ile anlamlı düzeyde ilișkilidir. ( $p<=0.05$ ). Sonuç: Sonuç olarak, spor okulu öğrencilerinin, sigara kullanımının zararlı etkileri konusundaki farkındalıklarını arttırmak ve halkın yoğun olarak sigarayı bırakmasını sağlamak için sağlık eğitimi programlarının sağlanmasında aktif rol almaları gerektiğine inanıyoruz.

Anahtar Kelimeler: Üniversite Öğrencileri, Yaygınlık, Sigara, Risk Faktörleri
Abstract: Objectives: Tobacco use increases the risk of death from many diseases, including ischemic heart disease, cancer, stroke, and respiratory diseases. In 2016 alone, tobacco use caused over 7.1 million deaths worldwide. Most of these deaths (6.3 million) were attributable to cigarette smoking, followed by secondhand smoke. Methods: The purpose of this study was to evaluate smoking prevalence and factors associated with smoking among students in Sports faculty of Istanbul University. The school has 360 students who are studying at the School of Sports and it is aimed to reach the whole school without selecting a sample. Results: The number of students who agree to participate in the study is $294(\% 81.94)$. Nearly $8 \%(n=24)$ smoked more than 10 cigarettes per day. The prevalence of smoking is significantly associated with the factors such as age, place of residence, mother's education, father's education level, cigarette or tobacco use at home, knowledge level of students concerning their teacher's smoking habit and alcohol consumption $(\mathrm{p}<=0.05)$. Conclusions: Consequently, we believe that students of sports school should take an active role in providing health education programs to increase awareness on detrimental effects of smoking and to quit smoking in public extensively.

Key Words: University Students, Prevalence, Cigarette, Risk Factors

Doi: 10.17363/SSTB.2018.2.3

(1) Sorumlu Yazar: Eray YURTSEVEN, Istanbul University, Cerrahpasa Medical Faculty, Department of Public Health, Istanbul / Turkey, eyurt@istanbul.edu.tr, Geliş Tarihi / Received: 23.02.2018, Kabul Tarihi / Accepted: 17.06.2018, Makalenin Türü: Type of article (Araştırma - Uygulama / Research -Application) Çıkar Çatışması / Conflict of Interest: Yok / None Etik Kurul Raporu/Ethics Committee: Yok / None 


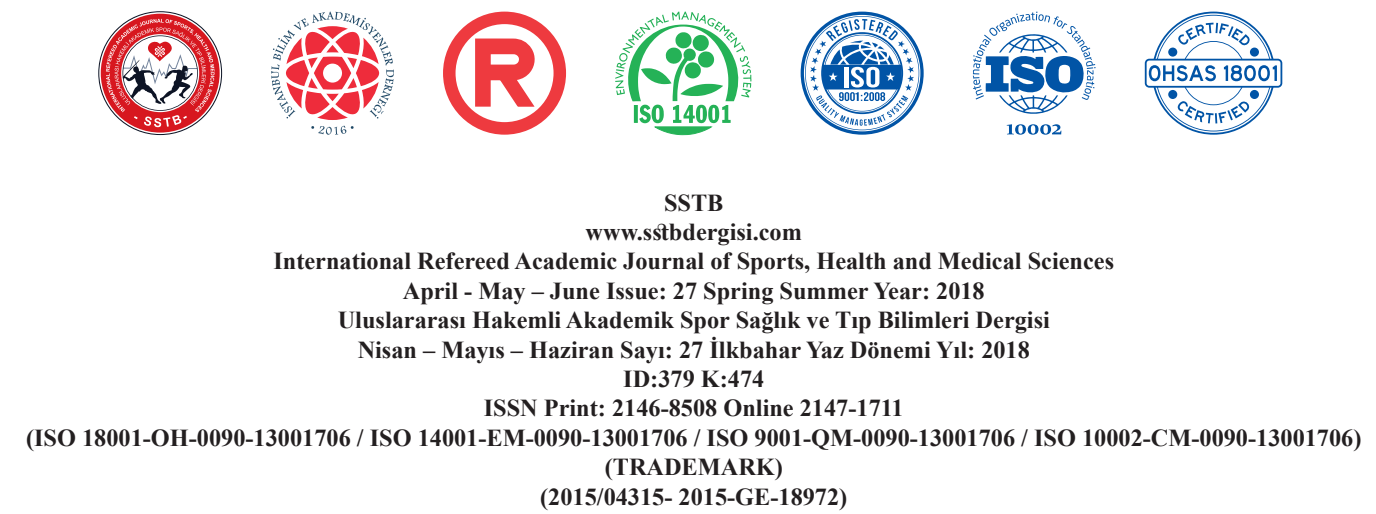

(2015/04315- 2015-GE-18972)

\section{INTRODUCTION}

Tobacco use is the single leading preventable cause of death all over the World. Based on the estimates done by the World Health Organization, in 2015 cigarette use will cause a $50 \%$ more death rate in comparison with HIV/AIDS; and $10 \%$ of the world's death rate will be connected to cigarette use (Kutlu, 2006:424-433; Mikolajczyk, 2008:19-23).

Tobacco use increases the risk of death from many diseases, including ischemic heart disease, cancer, stroke, and respiratory diseases. In 2016 alone, tobacco use caused over 7.1 million deaths worldwide (5.1 million in men, 2.0 millionin women). Most of these deaths (6.3 million) were attributable to cigarette smoking, followed by secondhand smoke ( 884.000 deaths). If necessary precautions are not taken according to the data released by World Health Organization (WHO), It has been estimated that 10 million people $(70 \%$ in developing countries) will die from a disease due to smoking in 2020 (Scarınc1, 2002:171-178; Wareen, 2006:1-3). Between 2002 and 2030, death rates in developed countries caused by cigarette use will be decreased by $9 \%$ (Peto, 2001:154-156). Turkey has made progress on tobacco control in recent years. However, people continue to die and become sick needlessly, and the costs to society from tobacco use continue to mount. Tobacco harms the health, the treasury, and the spirit of Turkey. Every year, more than 65300 of its people die of tobacco-caused disease. Still, more than 186000 children (10-14 years old) and 14786000 adults (15+ years old) continue to use tobacco each day (Trude, 2007:277285; Saad, 2016:175-178). Consistent with lower female smoking prevalence in many countries, the tobacco-related burden in women is lower than in men globally. However, with recent increases in smoking prevalence among female adolescents in some countries, this pattern may not continue. The United States spends nearly $\$ 170$ billion on medical care to treat smoking-related disease in adults each year. Tobacco control advocates must reach out to other communities and resources to strengthen their efforts and create change (Everett, 1998:137-140; Sezer, 2007:107-111; Trude, 2007:277-285). Considering the fact that cigarette use differs from one country to another, conducting studies on all countries and their cultures lays the foundation of more efficient planning. By now, we know that tobacco kills more than half of those who regularly use it and has a two trillion-dollar (purchasing power parity (PPP)) economic cost to society each year. There is a severaldecade lag between changes in smoking prevalence and changes in smoking-related death rates in the population (Peto, 2001:154156; Saad, 2016:175-178). The prevalence 
International Refereed Academic Journal of Sports, Health and Medical Sciences April - May - June Issue: 27 Spring Summer Year: 2018

Uluslararası Hakemli Akademik Spor Sağlık ve Tıp Bilimleri Dergisi

Nisan - Mayıs - Haziran Sayı: 27 İlkbahar Yaz Dönemi Yıl: 2018 ID:379 K:474

ISSN Print: 2146-8508 Online 2147-1711

(ISO 18001-OH-0090-13001706 / ISO 14001-EM-0090-13001706 / ISO 9001-QM-0090-13001706 / ISO 10002-CM-0090-13001706) (TRADEMARK)

(2015/04315- 2015-GE-18972)

of cigarette use among medical students of different academic years varies from $15 \%$ to $20 \%$, which is less in comparison with other developing countries in the region, such as Pakistan and Turkey. Based on reported reviews, in Turkey the maximum prevalence is 33\% (Sezer, 2007:107-111). This study was conducted with the intention of determining the prevalence of cigarette use among sport faculty students and the related causal factors.

\section{MATERIAL and METHODS}

A descriptive, exploratory study design was used to describe and identify smoking habits, beliefs, and attitudes towards smoking. The study was conducted during the academic year $2017 / 2018$. The population under study was all students enrolled in Istanbul University of Sport Science Faculty. The school has 360 students who are studying at the School of Sports and it is aimed to reach the whole school without selecting a sample. The number of students who agree to participate in the study is 294 (\%81.94). In this survey, exclusion criteria included subjects having health problems, being absent from school on the day of the study and did not agree to participate in the study. These questions were translated into Turkish from U.S version for the classification of smoking status (Sezer, 2007:107-111; Pampel, 2006:466487; İlhan, 2005:188-198). A questionnaire consisted of 40 items was administered to determine participants' socio-demographic characteristics, the knowledge, attitude and behaviour concerning smoking. The purpose of this study was to focus upon the habits, attitudes, and practices related to smoking behaviours of students at a university in Turkey. In accordance with the Helsinki Declaration Principles, "Informed consent" was obtained from people who participated in the approval and work of the Ethics Committee of the Faculty of Medicine. The obtained data were evaluated in the SPSS 15.0 and percentages in statistical analysis, t-test chi-square test and logistic regression analysis were used in independent groups. All statistical analysis was done at 95\% confidence level ( $\mathrm{p}$ value under 0.05 was considered significant).

\section{RESULT}

In total, 360 questionnaires were distributed to students, of which 294 were returned and used for analysis (81.94\% response rate). From the 294 respondents participated in the study, 138 (46.9\%) were men, 156 (53.1\%) were women. The mean age of respondents was 20.85 \pm 2.49 years (range, 18-32 years). Nearly $33 \%(n=97)$ of the participants had experienced cigarette use in their lifetime and $14 \%(n=41)$ participants were current smokers $(21 \%$ of men and $8 \%$ of women). Nearly $8 \%(\mathrm{n}=24)$ smoked more than 
SSTB

www.sstbdergisi.com

International Refereed Academic Journal of Sports, Health and Medical Sciences April - May - June Issue: 27 Spring Summer Year: 2018

Uluslararası Hakemli Akademik Spor Sağlık ve Tıp Bilimleri Dergisi

Nisan - Mayıs - Haziran Sayı: 27 İlkbahar Yaz Dönemi Yıl: 2018 ID:379 K:474

ISSN Print: 2146-8508 Online 2147-1711

(ISO 18001-OH-0090-13001706 / ISO 14001-EM-0090-13001706 / ISO 9001-QM-0090-13001706 / ISO 10002-CM-0090-13001706) (TRADEMARK)

(2015/04315- 2015-GE-18972)

10 cigarettes per day. Socio-demographic characteristics and factors associated with smoking habits of the participants were shown in Table 1. The prevalence of smoking is significantly associated with the factors such as age, place of residence, mother's education, father's education level, cigarette or tobacco use at home, knowledge level of students concerning their teacher's smoking habit and alcohol consumption $(\mathrm{p}<=0.05)$. It was found that the prevalence of smoking was significantly higher among students who had alcohol consumption and those who knew that their teacher was smoking. Prevalence of smoking did not significantly differ by sex and also classroom grades ( $p>0.05)$. Prevalence of smoking decreased as mother's education increased.

Table 1. Socio-Demographic Characteristics and Smoking Status of Students

\begin{tabular}{|c|c|c|c|c|c|c|c|}
\hline \multirow[t]{3}{*}{ Variable } & \multicolumn{7}{|c|}{ Smoking status } \\
\hline & \multicolumn{2}{|c|}{ Smoker } & \multicolumn{2}{|c|}{ Non-smoker } & \multicolumn{2}{|c|}{ Total } & \multirow[t]{2}{*}{$P$ value } \\
\hline & $\mathrm{N}$ & $\%$ & $\mathrm{~N}$ & $\%$ & $\mathrm{~N}$ & $\%$ & \\
\hline \multicolumn{8}{|l|}{ Gender } \\
\hline Male & 29 & 70.7 & 109 & 43.08 & 138 & 44.5 & \multirow[t]{2}{*}{$\mathrm{p}: 0.761$} \\
\hline Female & 12 & 29.3 & 144 & 56.92 & 156 & 55.5 & \\
\hline \multicolumn{8}{|l|}{ Grade } \\
\hline 1th & 17 & 41.4 & 63 & 24.9 & 80 & 27.2 & \multirow{4}{*}{$\mathrm{p}: 0.193$} \\
\hline 2 th & 10 & 24.4 & 67 & 26.9 & 77 & 26.2 & \\
\hline 3 th & 8 & 19.5 & 65 & 25.7 & 73 & 24.8 & \\
\hline 4 th & 6 & 147 & 58 & 22.5 & 64 & 21.8 & \\
\hline \multicolumn{8}{|c|}{ Age (years) } \\
\hline $18-20$ & 5 & 12.2 & 97 & 38.3 & 102 & 34.7 & \multirow{4}{*}{$\mathrm{p}<=0.05$} \\
\hline $21-23$ & 16 & 39.1 & 98 & 38.4 & 114 & 38.8 & \\
\hline $24-26$ & 11 & 26.8 & 37 & 14.6 & 48 & 16.3 & \\
\hline$>27$ & 9 & 21.1 & 21 & 8.7 & 30 & 10.2 & \\
\hline \multicolumn{8}{|c|}{ Type of graduated high school } \\
\hline Public & 36 & 87.8 & 207 & 81.8 & 243 & 82.6 & \multirow[t]{2}{*}{$\mathrm{p}<=0.05$} \\
\hline Private & 5 & 12.2 & 46 & 18.2 & 51 & 17.4 & \\
\hline
\end{tabular}

Place of residence 
SSTB

www.sstbdergisi.com

International Refereed Academic Journal of Sports, Health and Medical Sciences April - May - June Issue: 27 Spring Summer Year: 2018

Uluslararası Hakemli Akademik Spor Sağlık ve Tıp Bilimleri Dergis

Nisan - Mayıs - Haziran Sayı: 27 İlkbahar Yaz Dönemi Yıl: 2018 ID:379 K:474

ISSN Print: 2146-8508 Online 2147-171

(ISO 18001-OH-0090-13001706 / ISO 14001-EM-0090-13001706 / ISO 9001-QM-0090-13001706 / ISO 10002-CM-0090-13001706) (TRADEMARK)

(2015/04315- 2015-GE-18972)

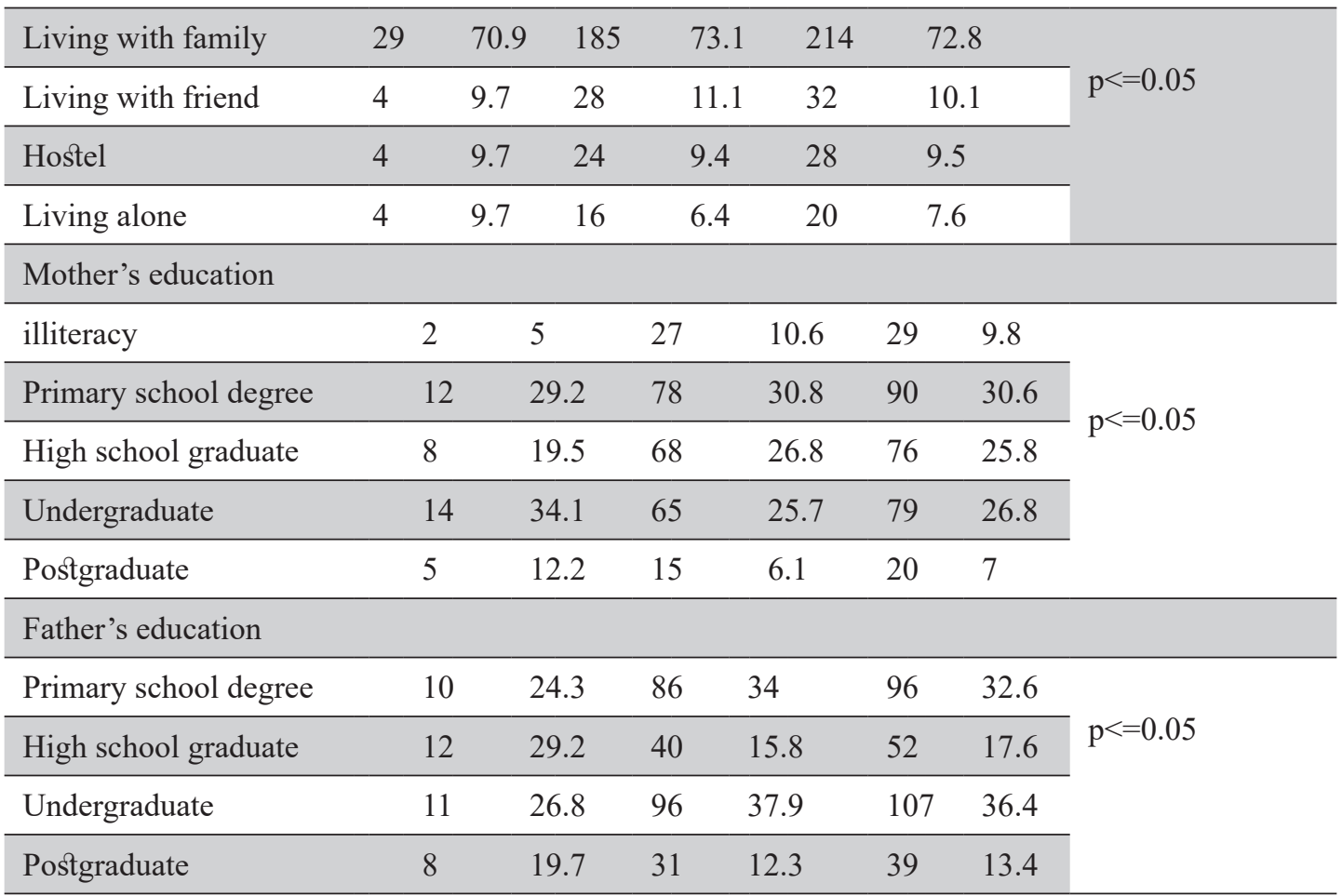

Cigarette or tobacco use in living place

\begin{tabular}{|c|c|c|c|c|c|c|c|c|}
\hline Not smoking & & 5 & 12.2 & 43 & 16.9 & 48 & 16.35 & \multirow{3}{*}{$\mathrm{p}<=0.05$} \\
\hline $\begin{array}{l}\text { Smoking } \\
\text { special } \\
\text { Area }\end{array}$ & in & 24 & 58.5 & 174 & 68.8 & 198 & 67.3 & \\
\hline $\begin{array}{l}\text { Smoking } \\
\text { every } \\
\text { Place }\end{array}$ & in & 12 & 29.3 & 36 & 14.3 & 48 & 16.35 & \\
\hline
\end{tabular}

Knowledge status of students on their teacher's smoking habit

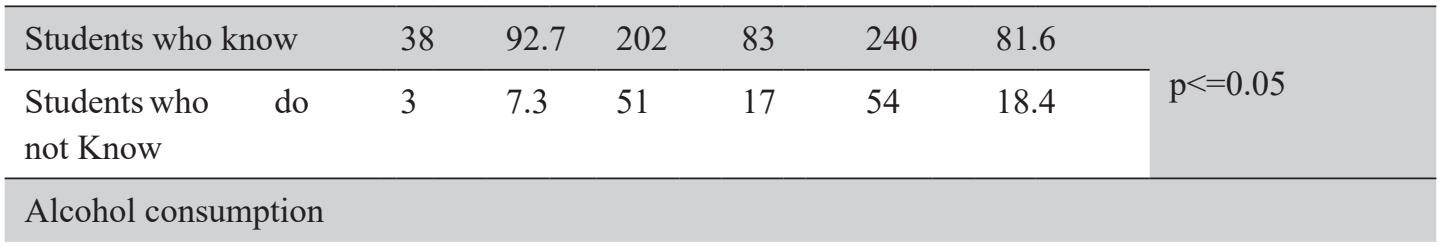

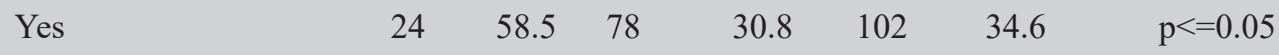


SSTB

www.sstbdergisi.com

International Refereed Academic Journal of Sports, Health and Medical Sciences April - May - June Issue: 27 Spring Summer Year: 2018

Uluslararası Hakemli Akademik Spor Sağlık ve Tıp Bilimleri Dergisi

Nisan - Mayıs - Haziran Sayı: 27 İlkbahar Yaz Dönemi Yıl: 2018 ID:379 K:474

ISSN Print: 2146-8508 Online 2147-1711

(ISO 18001-OH-0090-13001706 / ISO 14001-EM-0090-13001706 / ISO 9001-QM-0090-13001706 / ISO 10002-CM-0090-13001706) (TRADEMARK)

(2015/04315- 2015-GE-18972)

Table 2 presents the results of the smoking habits and complaints reported by students who smoke ( $\mathrm{n}=41) .95 .5 \%$ of students thought that cigarettes to children who are under age of 18 years should not be sold. 92.1\% students reported that the law for restriction of smoking indoor spaces has been required.
Number of the participants who reported that Doctors should convince the smokers to quit smoking was 194 (35.9\%), while 174(32.1\%) respondents indicated that the important task should be conducted by sportsman as shown in table 3 .

\section{Table 2. Considerations About the Harms of Cigarettes}

\begin{tabular}{lll} 
Behaviour & Number (n) & Percentage (\%) \\
\hline *Causes of smoking initiation & & \\
\hline Friends influence & 32 & 30.7 \\
\hline Affectation & 17 & 16.3 \\
\hline Curiosity & 21 & 20.2 \\
\hline Family conflicts & 7 & 6.9 \\
\hline School conflicts & 15 & 14.4 \\
\hline Loneliness & 12 & 11.5 \\
\hline Complaints associated with smoking & & \\
\hline Dyspnea & 18 & 13.6 \\
\hline Cough & 26 & 19.7 \\
\hline Decreasing physical activity & 16 & 12.1 \\
\hline Mouth wounds & 8 & 6.1 \\
\hline Bad smell of cigarette & 47 & 35.6 \\
\hline No complaint & 17 & 12.9 \\
\hline Do you want to quit smoking? & & 70.7 \\
\hline Yes & 29 & 29.3 \\
\hline No & 12 & \\
\hline * More than one choice were marked by respondents (n=41) answered this question.
\end{tabular}


SSTB

www.sstbdergisi.com

International Refereed Academic Journal of Sports, Health and Medical Sciences April - May - June Issue: 27 Spring Summer Year: 2018

Uluslararası Hakemli Akademik Spor Sağlık ve Tıp Bilimleri Dergis

Nisan - Mayıs - Haziran Sayı: 27 İlkbahar Yaz Dönemi Yıl: 2018 ID:379 K:474

ISSN Print: 2146-8508 Online 2147-1711

(ISO 18001-OH-0090-13001706 / ISO 14001-EM-0090-13001706 / ISO 9001-QM-0090-13001706 / ISO 10002-CM-0090-13001706) (TRADEMARK)

(2015/04315- 2015-GE-18972)

Table 3. Participants' General Thoughts on Smoking

\begin{tabular}{|c|c|c|}
\hline Attitude & Number (n) & $\begin{array}{l}\text { Percentage } \\
(\%)\end{array}$ \\
\hline \multicolumn{3}{|c|}{ On the law of smoking forbidden in all indoors } \\
\hline Necessary & 271 & 92.1 \\
\hline Not necessary & 11 & 3.9 \\
\hline Not important & 12 & 4.0 \\
\hline
\end{tabular}

Application of laws associated with smoking or tobacco use in the scenes of Film and Movies

\begin{tabular}{lll}
\hline Necessary & 203 & 69 \\
& & \\
Not necessary & 67 & 22.8 \\
\hline Not important & 24 & 8.2 \\
\hline Application of health risks of smoking warnings on cigarette packets & \\
\hline Sufficient & 204 & 69.3 \\
\hline Insufficient & 35 & 12.0 \\
\hline Not important & 55 & 18.7 \\
\hline On the prices of cigarette or tobacco & & \\
\hline More expensive & 234 & 79.6 \\
\hline Suitable & 12 & 4.1 \\
\hline More cheaper & 20 & 6.8 \\
\hline not affect & 28 & 9.5 \\
\hline
\end{tabular}

Opinions on selling cigarette to the children under the age of 18 years

\begin{tabular}{lll}
\hline Not sold & 281 & 95.5 \\
\hline parent's commission & 9 & 3 \\
\hline Free & 4 & 1.5
\end{tabular}

Having a training about health risks of smoking before

\begin{tabular}{lll}
\hline Yes & 86 & 29.3 \\
\hline No & 208 & 70.7
\end{tabular}

*What do you think about, whose mission convince to public for smoking cessation?

\begin{tabular}{lll}
\hline Doctor & 194 & 35.9 \\
\hline Teacher & 108 & 19.9 \\
\hline
\end{tabular}


SSTB

www.sstbdergisi.com

International Refereed Academic Journal of Sports, Health and Medical Sciences April - May - June Issue: 27 Spring Summer Year: 2018

Uluslararası Hakemli Akademik Spor Sağlık ve Tıp Bilimleri Dergisi

Nisan - Mayıs - Haziran Sayı: 27 İlkbahar Yaz Dönemi Yıl: 2018 ID:379 K:474

ISSN Print: 2146-8508 Online 2147-1711

(ISO 18001-OH-0090-13001706 / ISO 14001-EM-0090-13001706 / ISO 9001-QM-0090-13001706 / ISO 10002-CM-0090-13001706) (TRADEMARK)

(2015/04315- 2015-GE-18972)

\begin{tabular}{lll}
\hline Sportsman & 174 & 32.1 \\
\hline Parents & 65 & 12.1 \\
\hline
\end{tabular}

* More than one choise were marked by respondents $(n=294)$ answered this question.

\section{DISCUSSION}

The great majority of smokers in this study started smoking after the age of 14. This is consistent with the results of several studies conducted in other countries. These findings show that the most common age of starting smoking was between 15 and 19 among all ever-smokers (Bawazeer, 1999:440-449). Young et al. (1989) set the age of onset as 20 years for the great majority of smokers and described adolescence as the most vulnerable period for acquiring the smoking habit (Young, 1989:142-148). This study found the prevalence to be $14 \%$ among sport faculty students. In Turkey, prevalence of smoking has been found $26.5 \%$ among the individuals who aged $\geq 18$ years according to the report released by fortune turkey 2017 . To determine prevalence of smoking, we can conduct various studies with different methodologies. In a study conducted by Dabak et al. reported that the prevalence of smoking was 29.2\% (Dabak, 1997:124). Another survey performed by Metintas et al. found that the prevalence of smoking was 42.5\% in Eskisehir (Metintas, 1998:261-264). Onadli et al. have reported that the prevalence of smoking was 47.0\% (Onadl1, 2005:487).
It is obviously clear that smoking status and sports are two opposite habits that should not coexist. Smoking decreases the performance of sport by affecting respiratory systems negatively as well as it has destructive effect on most systems and vital organs. In near future smoking will cause bad, breath dry skin and lower sport performance. Most developing countries report high rates of male smokers and low rates of female smokers. The WHO indicated that men smoke nearly five times as much as women, but the ratios of female-to-male smoking prevalence rates vary dramatically across countries. In high-income countries, including Australia, Canada, the United States of America and most countries of western Europe, women smoke at nearly the same rate as men (Schaap, 2009:271-278). However, in many low- and middle- income countries women smoke much less than men. In China, for example, $61 \%$ of men are reported to be current smokers, compared with only $4.2 \%$ of women. Similarly, in Argentina 34\% of men are reported to be current smokers, compared with $23 \%$ of women [WHO, 2008:1-2]. Although in the present study we determined that the prevalence of smoking 


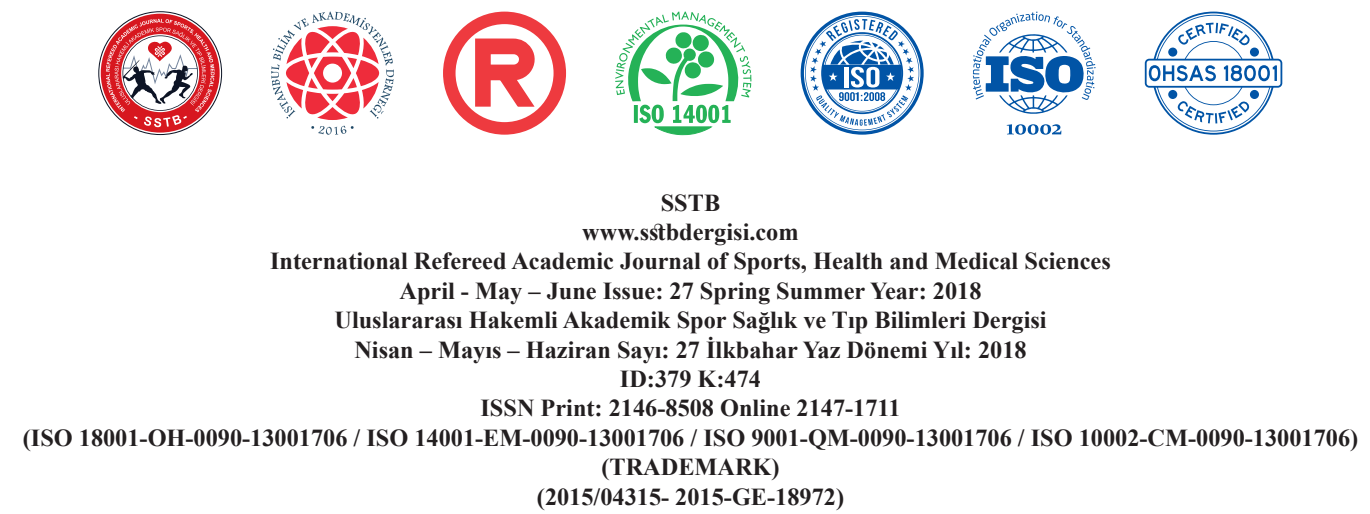

(2015/04315- 2015-GE-18972)

among women was higher than men, the difference was not statistically significant. Valente et al. reported that $93.1 \%$ smokers initiated smoking with friends (Valente, 2005:323-329). In another study conducted by Ilhan et al. revealed that $36.7 \%$ of the smokers have begun smoking by reason of "friends' effect", 19.0\% "affectation", and 18.1\% "curiosity" (Ilhan, 2005:188-198). The present study found that the factors associated with the reasons of smoking initiation were friends' effect, curiosity, affectation, school conflicts and loneliness (30.7\%, 20.2\%, 16.3\%, 14.4\% , and 11.5\% respectively). In fact, among more than 12 cited articles on university students in Saudi Arabia, an overall tobacco consumption was found to range from $2.4 \%$ to $37 \%$; while the range of consumption among male students ranged between $13 \%$ and $37 \%$ and among female students to range from $1 \%$ to $16 \%$ (Abdelshakour, 2007:1102-1108). Although our reported prevalence estimates seem to fall within ranges of similar studies carried out on Saudi university students, yet we think that the much lower female smoking prevalence may be attributed to "social stigma" of smoking, that women may be more conservative and more health-aware about the drawbacks and consequences of smoking. In our study, no relation was found in terms of gender and grade of classroom, marital status as well as the father's education level did not show an association. In a study on American college students, those who were classified as single were $36 \%$ more likely to smoke; however, in a similar study, parent's education level did not appear to be significant (Everett, 1998:137140). In this study we found that difference was statistically significant for cigarette and alcohol. In other studies also association between the simultaneous use of cigarette and alcohol was seen so much so that these cigarettes and alcohol are considered to be gateway substances. Previous studies have found that there has been a significant association between smoking initiation of students and family's socioeconomic status and education level (Lam, 2002:135138; Mcginnis, 1993:2207-2212; Linda, 2002:793-802). But Assanelli et al. showed that no difference was found with respect to age with smoking (Assanell1, 1991:457465; Abdelshakour, 2007:1102-1108). This result was different from the result that we obtained in our study. In our study with an increasing age and school grade, the smoking habit is going to reduce. We have estimated that it was an effect of sport activity, of competition and the case the lung function is progressively decreasing with the number of smoked cigarettes, then the performance is impaired. Students also believed that price of cigarettes must be expensive and cigarette sales to individuals under the age 


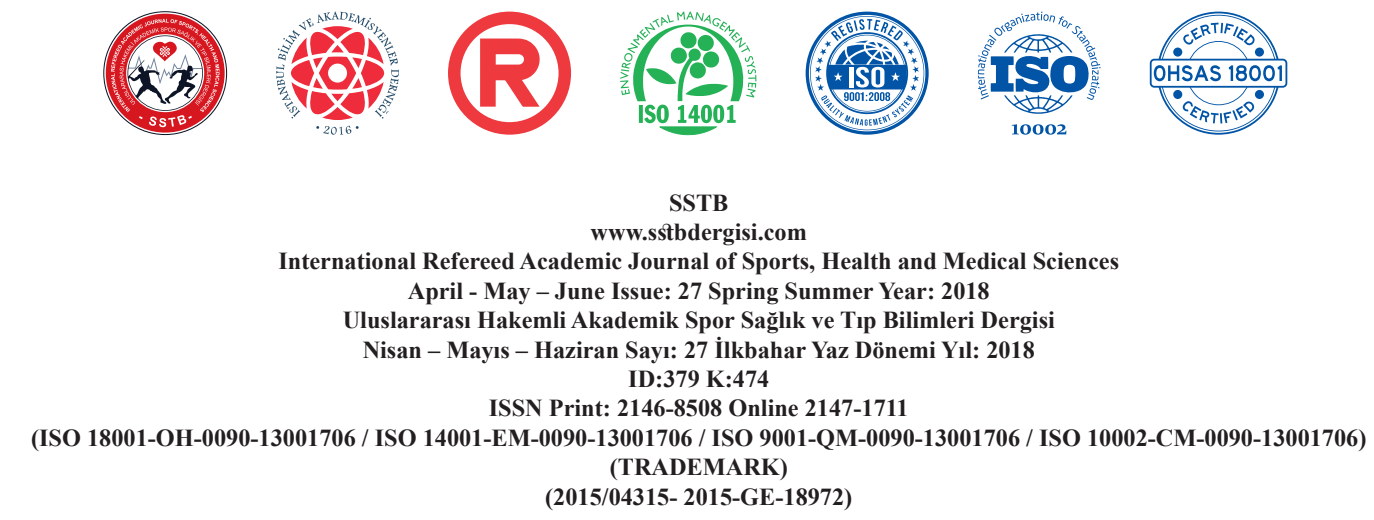

of 18 should be strictly forbidden to decrease smoking. The results of the current study were consistent with the study of Atilla et al (Atilla, 2007:364-370). Intensive antismoking efforts in developed countries have decreased gradually the frequency of smoking in these countries (Pampel, 2006:466-487; Saad, 2016:175-178). It is considered that cigarettes are cheaper in developing countries such as Turkey, individuals in every age group can easily reach cigarettes and insufficient smoking cessation campaigns are the most significant reasons for this situation. The findings our study support this assessment. Nighty five percent of participants reported that cigarettes should not be sold certainly to people under the age of 18 . One of the important findings in the literature is that the vast majority of the students have known the harmful effects of smoking (Lam, 2002:135-138; Mcginnis, 1993:22072212; Peto, 2001:154-156). These previous results were similar to the findings in the present study. There are some limitations in our research. The first limitation of our study was that smoking habits related to risk factors of the students were determined by using self-administrated questionnaire without physiological or biochemical measurements. Thus, the prevalence of smoking found in the study, may have been influenced by recall bias. Comparing with the literature, the low rate of smoking prevalence may result from the responders that may have underestimated their own smoking behaviour because of the idea that students studying at the departments of physical education and sports should not smoke. The second limitation was related to the type of study design. It is known that the cross-sectional design is not suitable for the evaluation of causal relationships between smoking status (dependent variable) and factors (independent variable) associated with smoking. Because of these limitations, we couldn't say that factors found in our study cannot be associated precisely with smoking.

\section{CONCLUSION}

Students of sports faculty know that smoking has detrimental effects on health. We found that fourteen percent of students were smokers in the present study. We suggest that health education programs related to smoking should be involved in the academic curriculum for both increasing their knowledge level on this issue and decreasing those of smoking habits. Special courses might be organized for sport students about hazards of smoking. Especially we recommend that lessons related to smoking and health issues should be offered. In addition, these programs should be supported together with post-graduate trainings to provide antismoking habits. According to the study 


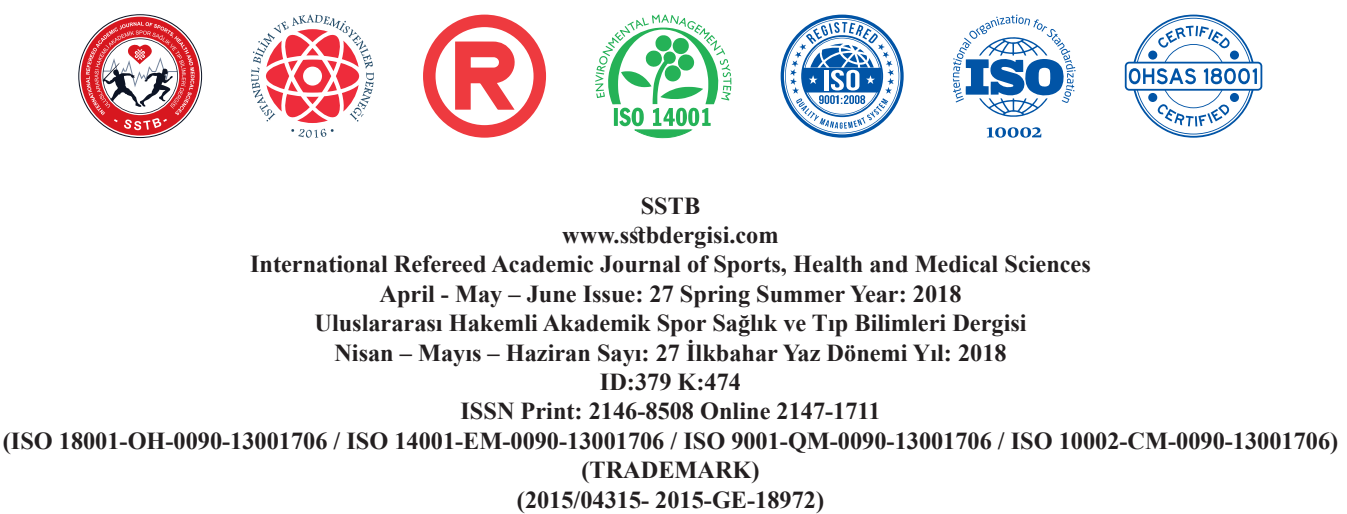

(2015/04315- 2015-GE-18972)

results, friends' influence was an important factor for smoking initiation. Therefore, the campaigns of smoking cessation should be planned for groups of friends not for the individual. Students should be given more active role in campaigns of smoking cessation and their awareness should be increased. Thus, the students who will be educating sportsmen of the future can be a role model for the society in terms of health promotion.

\section{Conflict of Interest}

The authors declare no conflict of interest.

\section{REFERENCES}

ABDELSHAKOUR, A., AL-KAABBA, A., SAEED, A., ABDULRAHMAN, M., $\boldsymbol{R} A \boldsymbol{A T}$ H., (2007). Gender Differences in Smoking Behavior Among Adolescents in Saudi Arabia. Saudi Med J, (28): 11021108

ASSANELLI, D., DONATO, F., MARCONI, M., CORSINI, C., TONINI, G., BONVINI, L., ROSA, G., NARDI, G., (1991). Smoking Habits and Sporting Activity Among Adolescents in North Italy. Revue d'Epidemiologie et de Sante Publique, 39(5): 457-65

ATILLA, S.M., TUFAN, N., BAŞTAŞ, S., (2007). Attitudes Towards Smoking and Frequency of Smoking Among
Students of Düzce Medical School. TAF

Preventive Medicine, 6(5): 364-70

BAWAZEER, A., HATTAB, A., MORALES, E., (1999). First Cigarette Smoking Experience Among Secondary-School Students in Aden, Republic of Yemen. Eastern Mediterranean Health Journal, 5(3): 440-449

DABAK, Ş., TOPBAŞ, M., DÜNDAR, C., (1997). Ondokuz Mayıs Üniversitesi Öğrencilerinde Sigara İçme Prevalansı. Sigara ve Sağlık Ulusal Kongresi, ss: 124

EVERETT, S.A., HUSTEN, C.G., WARREN, C.W., CROSSETT, L., SHARP, D., (1998). Trends in Tobacco Use Among High School Students in The United States, 1991-1995. J Sch Health, 68(4): 137-140

KUTLU, R., (2006). The Prevalence Alence Of Smoking Among The Students of Meram Apprenticeship School. TAF Preventive Medicine Bulletin, 5(6): 42433

LAM, T.H., JIANG, C.Q., HO, S.Y., ZHANG, W.S., LIU, W.W., HE, J.M., (2002). Smoking and Mortality in 1,344 Drivers in Guangzhou, China. Occup Environ Med (59): 135-8

METINTAŞ, S., SARIBOYACI, M.A., NUHOĞLU, S., (1998). Smoking 
International Refereed Academic Journal of Sports, Health and Medical Sciences April - May - June Issue: 27 Spring Summer Year: 2018

Uluslararası Hakemli Akademik Spor Sağlık ve Tıp Bilimleri Dergisi

Nisan - Mayıs - Haziran Sayı: 27 İlkbahar Yaz Dönemi Yıl: 2018 ID:379 K:474

ISSN Print: 2146-8508 Online 2147-1711

(ISO 18001-OH-0090-13001706 / ISO 14001-EM-0090-13001706 / ISO 9001-QM-0090-13001706 / ISO 10002-CM-0090-13001706) (TRADEMARK)

Patterns of University Students in Eskişehir, Turkey. Public Health, 112(4): 261-64

ILHAN, F., AKSAKAL, N., ILHAN, M.N., $A Y G \ddot{U} N$, R., (2005). Smoking Prevalence Among Gazi University Faculty of Medicine. TAF Preventive Medicine, (4): $188-98$

MCGINNIS, J.M., FOEGE, W.H., (1993). Actual Causes of Death in the United States. JAMA (270): 2207-2212

MIKOLAJCZYK, R.T., MAXWELL, A.E., NAYDENOVA, V., MEIER, S., ELANSARI, W., (2008). Depressive Symptoms and Perceived Burdens Related to Being a Student: Survey in Three European countries. Clin Pract Epidemol Ment Health, (4): 19-23

ONADLI, C.T., BILIR, N., ASLAN, D., (2005). Tütün Eksperliği Yüksek Okulu Mezunları ile Öğrencilerinin Sigara Ölçme Durumları. 9.Ulusal Halk Sağlığ 1 Günleri-GATA (Çevre Sağlığı) Bildiri Kitab1, ss: 478

PAMPEL, F.C., (2006). Global Patterns and Determinants of Sex Differences in Smoking. Int J Comp Sociol, (47): 466-87 doi: 10.1177/0020715206070267

PETO, R., LOPEZ, A.D., (2001). Future Worldwide Health Effects of Current
Smoking Patterns. In: Koop CE, Pearson CE, Schwarz MR, editors. Critical issues in global health. San Francisco: Wiley (Jossey-Bass); pp. 154-6

SAAD, G., AL-GHANEEM, OSAMA., ALNEFISAH, S., (2016). The Prevalence of smoking Among Male Students of Majmaah University, KSA. Journal of Taibah University Medical Sciences, 11(2): 175-178

SCARINCI, I.C., ROBINSON, L.A., ALFANO, C.M., ZBIKOWSKI, S.M., KLESGES, R.C., (2002). The Relationship Between Socioeconomic Status, Ethnicity, and Cigarette Smoking in Urban Adolescents. Prev Med, (34): $171-8$

SCHAAP, M.M., KUNST, A.E., LEINSALU, M., REGIDOR, E., ESPELT, A., EKHOLM, O., et al., (2009). Female EverSmoking, Education, Emancipation and Economic Development in 19 European Countries. Soc Sci Med 68: 271-8 doi: 10.1016/j.socscimed.2009.01.007 pmid: 19195749

SEZER, H., GULER, N., SEZER, R.E., (2007). Smoking Among Nurses in Turkey: Comparison with Other Countries. J Health Popul Nutr, 25(1): 107-111 
International Refereed Academic Journal of Sports, Health and Medical Sciences April - May - June Issue: 27 Spring Summer Year: 2018

Uluslararası Hakemli Akademik Spor Sağlık ve Tıp Bilimleri Dergisi

Nisan - Mayıs - Haziran Sayı: 27 İlkbahar Yaz Dönemi Yıl: 2018 ID:379 K:474

ISSN Print: 2146-8508 Online 2147-1711

(ISO 18001-OH-0090-13001706 / ISO 14001-EM-0090-13001706 / ISO 9001-QM-0090-13001706 / ISO 10002-CM-0090-13001706) (TRADEMARK)

TRUDE, D., SKORGE, M.L., EIDE, WHO (2008). Report on the global tobacco

G.E., GULSVIK, A., BAKKE, S.P., (2007). Exposure to Environmental

Tobacco Smoke in a General Population.

Respiratory Medicine, (101): 277-85

VALENTE, T.W., UNGER, B.J., JOHNSON, C.A., (2005). Do Popular Students Smoke? The Association Between Popularity and Smoking Among Middle School Students. J Adolescent Health 2005, 37(4): 323-29

WARREN, C.W., JONES, N.R., (2006). The Global Tobacco Surveillance System. Tob Control 15, (Suppl 2): 1-3 epidemic, 2008: the MPOWER package. Geneva: World Health Organization; pp.1-2

LINDA, G., MALAK, Z., (2002). Smoking Habits and Attitudes Towards Smoking Among University Students in Jordan. International Journal of Nursing Studies, 39 (2002) 793-802

YOUNG, D., SWAN, A., MELIA, J., (1989).

Cigarette Advertising And The Youth Market. Health Education Journal, 48(3): 142-148 